Die rol van die US se Departement Afrikaans en Nederlands in die ontwikkeling van die Afrikaanse leksikografie: Die Nederlands-Afrikaans-stryd gedurende die aanvangsjare

The role of Stellenbosch University's Department of Afrikaans and Dutch in the development of Afrikaans lexicography: The Dutch-Afrikaans battle during the formative years

\title{
Gerda Odendahl
}

Universiteit Stellenbosch

Departement Afrikaans en Nederlands

E-pos: godendaal@sun.ac.za

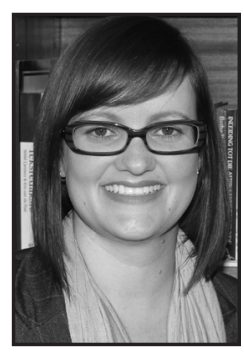

Gerda Odendaal

Gerda OdendaAl is verbonde aan die Universiteit Stellenbosch waar sy sedert 2013 'n nadoktorale genoot in die Departement Afrikaans en Nederlands is. Sy behaal in 2012 haar $\mathrm{PhD}$ aan dieselfde universiteit nadat haar magisterstudie na 'n doktorale studie omgeskakel is. As toppresteerder in die Universiteit Stellenbosch se Fakulteit Lettere en Sosiale Wetenskappe ontvang sy twee keer 'n Rektorstoekenning vir Uitnemende Prestasie in Akademie. Verskeie beurse en vakpryse is ook aan haar toegeken. Sy hou haar tans besig met navorsing in die sosiolinguistiek, taalbeplanning en leksikografie, en woon gereeld plaaslike en internasionale kongresse by.
Gerda OdendaAl is affiliated to Stellenbosch University where she is a postdoctoral fellow at the Department of Afrikaans and Dutch since 2013. She obtained her $\mathrm{PhD}$ at the same university in 2012 after her master's study was upgraded to a doctoral study. As a top student in Stellenbosch University's Faculty of Arts and Social Sciences, she received a Rector's Award for Excellence in Academics twice in a row. She has also been awarded various other prizes and bursaries. Her research interests include sociolinguistics, language planning and lexicography, and she regularly attends local and international conferences.

\section{ABSTRACT \\ The role of Stellenbosch University's Department of Afrikaans and Dutch in the development of Afrikaans lexicography: The Dutch-Afrikaans battle during the formative years \\ In many respects Stellenbosch University can be regarded as the cradle of Afrikaans lexicography. It is home to one of the most comprehensive and lengthy lexicographic projects in Afrikaans, the Woordeboek van die Afrikaanse Taal ("Dictionary of the Afrikaans Language"). Being one of the first university departments in South Africa to appoint a Chair for Afrikaans in 1920, the Department of Afrikaans and Dutch especially played an important role in developing the Afrikaans lexicography.}


However, not everyone in die Department of Afrikaans and Dutch was convinced from the outset that Afrikaans could or even should make its mark in the field of lexicography. It was, in fact, a lecturer of Dutch who first alluded to the fact that Afrikaans is distinct from Dutch through his lexicographic work on Afrikaans. This uncertainty about Afrikaans'ability to gain lexicographic independence gave rise to great contention between Afrikaans and Dutch during the early years of Afrikaans lexicography, especially in Stellenbosch University's Department of Afrikaans and Dutch. It resulted, amongst other things, in lexicographers often relying heavily on Dutch in the lexicographical embodiment of Afrikaans.

This article investigates the role of Stellenbosch University's Department of Afrikaans and Dutch in the development of Afrikaans lexicography amidst an intense Dutch-Afrikaans battle during the formative years of Afrikaans lexicography. Firstly, the paper shows why the dictionary Proeve van een Kaapsch-Hollandsch Idioticon met Toelichtingen en Opmerkingen betreffende Land, Volk en Taal by the Dutch lecturer at Stellenbosch, Nicolaas Mansvelt, could be regarded as the genesis of Afrikaans lexicography. It is shown that, by studying Afrikaans as a language independent from Dutch, Mansvelt broke away from the tradition of his time which often viewed Afrikaans as a depraved form of Dutch, thereby making an important contribution to the development of Afrikaans lexicography.

This is followed by an overview of the initial battle in the Afrikaans speech community between proponents of Dutch and Afrikaans that took place in the period during which Stellenbosch University distinguished itself as an Afrikaans university. On the one hand there was a pro-Dutch movement, led by Stellenbosch lecturer W.J. Viljoen, which sought to make Dutch the future language of South Africa by introducing a simplified form of Dutch, the Vereenvoudigde Nederlandse Spelling ("Simplified Dutch Spelling"), through the publication of various dictionaries. On the other hand the pro-Afrikaans movement, consisting mostly of students under the leadership of the first lecturer of Afrikaans at Stellenbosch, J.J. Smith, campaigned for Afrikaans to be adopted as medium of instruction at Stellenbosch University. The two opposing parties were eventually united in the formation of the Suid-Afrikaanse Akademie vir Wetenskap en Kuns ("South African Academy for Science and Arts") which endeavoured to develop both Dutch and Afrikaans in South Africa.

Although the initial idea with the formation of the Academy was to create a truce between the proponents of Dutch and Afrikaans, this battle continued with the compilation of the specialpurpose dictionary, the Afrikaanse woordelys en spelreëls ("Afrikaans word list and spelling rules") by the Academy's Taalkommissie ("Language Commission"), on which several lecturers from Stellenbosch University's Department of Afrikaans and Dutch served over the years. As a special-purpose dictionary the Afrikaanse woordelys en spelreëls promoted the standard spelling of Afrikaans which would have an influence on several bilingual and descriptive dictionaries in later years. The focus in the next part of the article thus falls on the continued Dutch-Afrikaans battle as it played itself out in the earlier editions of the Afrikaanse woordelys en spelreëls, this time with Smith campaigning for more Dutch forms, and the resulting influence of Dutch on the development of Afrikaans orthography, especially as it relates to the spelling of loanwords.

Finally it is shown how Afrikaans orthography gained independence as it was gradually freed from Dutch influence in subsequent editions of the Afrikaanse woordelys en spelreëls. In closing it is, however, suggested that, although great strides have been made in the development of an independent Afrikaans orthography, the Dutch-Afrikaans battle has had a lasting influence on Afrikaans lexicography through this special-purpose dictionary. 
KEYWORDS: $\quad$ Department of Afrikaans and Dutch, Stellenbosch University, Afrikaans, Dutch, lexicography, language battle, Mansvelt, Idioticon, W.J. Viljoen, "Simplified Dutch Spelling", J.J. Smith, "Afrikaans Language Association", "Afrikaans word list and spelling rules", "Language Commission", "Dictionary of the Afrikaans Language"

TREFWOORDE: Departement Afrikaans en Nederlands, Universiteit Stellenbosch, Afrikaans, Nederlands, leksikografie, taalstryd, Mansvelt, Idioticon, W.J. Viljoen, Vereenvoudigde Nederlandse Spelling, J.J. Smith, Afrikaanse Taalvereniging, Afrikaanse woordelys en spelreëls, Taalkommissie, Woordeboek van die Afrikaanse Taal

\section{OPSOMMING}

Die studie stel ondersoek in na die rol van die Universiteit Stellenbosch se Departement Afrikaans en Nederlands in die ontwikkeling van die Afrikaanse leksikografie te midde van 'n fel NederlandsAfrikaans-stryd in die wordingsjare van die Afrikaanse leksikografie. Daar word eerstens gefokus op die aanvang van die Afrikaanse leksikografie aan die Universiteit Stellenbosch deur die publikasie van Mansvelt se Idioticon. Vervolgens word 'n oorsig gegee oor die spellingstryd tussen die voorstanders van Nederlands, met W.J. Viljoen aan die stuur, en die voorstanders van Afrikaans, onder leiding van J.J. Smith, beide dosente aan die Universiteit Stellenbosch, wat geheers het in die tydperk waarin hierdie universiteit hom as 'n Afrikaanse universiteit onderskei het. Ten slotte word gedui op die voortgesette Nederlands-Afrikaans-stryd soos wat dit in die daaropvolgende jare in die woordeboek vir spesiale doeleindes, die Afrikaanse woordelys en spelreëls, tot uitdrukking gebring is en die blywende invloed wat die stryd op die Afrikaanse spelling gehad het.

\section{INLEIDING}

Die Universiteit Stellenbosch kan in baie opsigte as die bakermat van die Afrikaanse leksikografie beskou word. Dit is naamlik hier waar een van die omvangrykste en langdurigste leksikografiese projekte in Afrikaans, die Woordeboek van die Afrikaanse Taal, 'n tuiste gevind het. As een van die eerste universiteitsdepartemente in Suid-Afrika wat reeds in 1920 'n leerstoel vir Afrikaans ingestel het, het veral die Departement Afrikaans en Nederlands 'n besondere aandeel gehad aan die uitbou van die Afrikaanse leksikografie tot internasionale standaard.

Almal in die Departement Afrikaans en Nederlands was egter nie uit die staanspoor daarvan oortuig dat Afrikaans sigself op leksikografiese gebied kon of selfs moes laat geld nie. Dit was naamlik 'n dosent in Nederlands wat met een van die eerste leksikografiese werke in Afrikaans op die eiesoortigheid van Afrikaans gedui het. Die onsekerheid oor Afrikaans se vermoë om op eie leksikografiese bene te staan het gelei tot 'n stryd tussen Afrikaans en Nederlands wat hom, veral binne die Universiteit Stellenbosch se Departement Afrikaans en Nederlands, telkens in die wordingsjare van die Afrikaanse leksikografie sou afspeel. Een van die gevolge hiervan was dat daar in die leksikografiese vergestalting van Afrikaans telkens op Nederlands gesteun is.

In hierdie inleidende studie ${ }^{1}$ oor die rol van die Universiteit Stellenbosch, maar in die besonder sy Departement Afrikaans en Nederlands, in die ontwikkeling van die Afrikaanse leksikografie,

\footnotetext{
1 Die artikel vorm deel van 'n omvattender projek van die Dekaan van die Fakulteit Lettere en Sosiale Wetenskappe van die Universiteit Stellenbosch oor die geskiedenis van die Fakulteit. Hierdie artikel is die eerste in 'n beoogde reeks artikels oor die rol van die Universiteit Stellenbosch se Departement Afrikaans en Nederlands in die ontwikkeling van die Afrikaanse leksikografie teen die agtergrond
} 
word daar veral gefokus op die Nederlands-Afrikaans-stryd gedurende die aanvangsjare van die Afrikaanse leksikografie. Eerstens word gefokus op die Nederlandse dosent, Nicolaas Mansvelt, se rol as leksikografiese baanbreker deur die publikasie van sy Proeve van een Kaapsch-Hollandsch Idioticon. Vervolgens word 'n oorsig gegee oor die stryd tussen die voorstanders van Nederlands, wat onder leiding van die Stellenbosse dosent, W.J. Viljoen, gepoog het om 'n vereenvoudigde Nederlandse spelling deur die publikasie van verskeie woordeboeke in te voer, en die voorstanders van Afrikaans, wat hulle onder die leierskap van nóg 'n Stellenbosser, J.J. Smith, beywer het om Afrikaans as onderrigmedium aan die Universiteit Stellenbosch erken te kry.

Daar word laastens gefokus op die voortgesette Nederlands-Afrikaans-stryd met die publikasie van die Afrikaanse woordelys en spelreëls, nou met Smith in die pro-Nederlandse kamp, en die gevolglike invloed wat Nederlands in die daaropvolgende jare op hierdie bron sou uitoefen. Die Afrikaanse woordelys en spelreëls kan as 'n woordeboek vir spesiale doeleindes beskou word, aangesien die bron 'n beperkte leksikale aanbod het, asook beperkte datakategorieë (Gouws \& Prinsloo 2005:47). Bewerking in dié bron is naamlik beperk tot "hedendaagse skriftelike, formele Standaardafrikaans" en dit "bereël slegs die ortografiese konvensies van Standaardafrikaans" (Taalkommissie 2009:xxiv). As woordeboek vir spesiale doeleindes wat die amptelike en gestandaardiseerde spelling vir Afrikaans bevorder het, het die Afrikaanse woordelys en spelreëls 'n belangrike invloed uitgeoefen op die tweetalige en verklarende woordeboeke wat in latere jare sou volg (Gouws \& Ponelis 1992:30). Enige oorsig oor die leksikografiese geskiedenis van Afrikaans sou dus onvolledig wees sonder die inagneming van hierdie bron.

\section{AANVANG VAN DIE AFRIKAANSE LEKSIKOGRAFIE: MANSVELT SE IDIOTICON}

In 1822 vaardig Lord Charles Somerset 'n proklamasie uit waarvolgens die Kaapkolonie op amptelike vlak verengels is (Kapp 2013:11). Teen die middel van die negentiende eeu het die onderwys ook grotendeels verengels deurdat skole nie toegelaat is om in Nederlands onderrig te gee nie (Van Keymeulen 2010:139; Kapp 2013:12). In 1864 neem Nederlandse ouers op Stellenbosch egter leiding met die stigting van Het Stellenbossche Gymnasium ${ }^{2}$ wat amptelik geopen is op 1 Maart 1866 (Du Toit \& Venter 1966a:21-22; Kapp 2013:12). Alhoewel onderrig in die skool in Engels plaasgevind het, is die gebruik van Nederlands as omgangstaal wel toegelaat. Na die toevoeging van 'n Arts Department tot die Gymnasium in 1874-1875, is daar, na aandrang op die onderrig van Nederlands, Frans en Duits, 'n Nederlander met name Nicolaas Mansvelt vir dié doel in September 1874 aangestel (Snijman 1964:3; Du Toit \& Venter 1966a:27; Kapp 2013:13). Mansvelt was later ook verantwoordelik vir letterkunde en algemene geskiedenis (Du Toit \& Venter 1966b:38-39).

As Nederlander wat nie vertroud was met die Kaaps-Hollands (oftewel Afrikaans) wat teen die einde van die negentiende eeu algemeen in die Kaapkolonie gebruik is nie, was Mansvelt, soos baie van sy tydgenote, geïnteresseerd in die verskille tussen Afrikaans en Standaardnederlands

van Afrikaans se stryd teen Nederlands. Die artikel bied nie 'n volledige oorsig oor dié Departement se rol in die ontwikkeling van die Afrikaanse leksikografie nie, maar slegs ' $n$ inleidende blik met 'n besondere fokus op die stryd tussen Nederlands en Afrikaans wat gedurende die aanvangsjare geheers het.

2 Ten einde amptelike erkenning van die Kaapse Departement van Onderwys te verkry, moes die naam verander word na Het Stellenbosch Gymnasium/Stellenbosch First Class Denominational School (Kapp 2013:13).

Tydskrif vir Geesteswetenskappe, Jaargang 56 No. 1: Maart 2016

doi.10.17159/2224-7912/2016/v56n1a16 
en die ooreenkomste tussen Afrikaans en die Nederlandse omgangstaal (Gouws \& Ponelis 1992:11). Hy het kort na sy aankoms in die Kaap op aanbeveling van 'n vriend begin om noukeurig aantekeninge te maak van alles wat hom vreemd opgeval het in die uitspraak of woordgebruik in KaapsHollands (Mansvelt 1884:iii-iv). Dit is egter veral in die omgang met sy leerlinge aan die Stellenbosch College ${ }^{3}$ dat Mansvelt onder die indruk gekom het van die belangrikheid om die "eigenaardigheden" van Kaaps-Hollands te omskryf ten einde wedersydse begrip tussen hom en sy leerlinge te bevorder (Mansvelt 1884:iv). So verskyn in 1884 met die hulp en aanmoediging van sy leerlinge sy Proeve van een Kaapsch-Hollandsch Idioticon met Toelichtingen en Opmerkingen betreffende Land, Volk en Taal (voortaan Idioticon; Mansvelt 1884:iv-v).

In dié woordeboek word woorde en uitdrukkings wat eie is aan Suid-Afrika (met ander woorde Kaaps-Hollandse/Afrikaanse woorde en uitdrukkings) in sowat 2000 lemmas oor 188 bladsye behandel (Mansvelt 1884:iii-v; Snijman 1964:3; Van der Merwe 1971:xiii). Alhoewel die taal van die makrostruktuur Afrikaans is, is die metataal van die leksikografiese bewerking Nederlands, sodat Idioticon volgens Gouws (1995:46) in werklikheid 'n tweetalige woordeboek is. Lemmas sluit in unieke Suid-Afrikaanse woorde en uitdrukkings, Nederlandse woorde wat ' $n$ betekenisverandering ondergaan het, woorde en uitdrukkings uit sewentiende-eeuse Hollands wat in SuidAfrika bly voortleef het maar in Nederland in onbruik geraak het, en woorde wat aan vreemde tale, in die besonder Maleis, ontleen is (Mansvelt 1884:v). Die artikelstruktuur bevat meestal semantiese kommentaar in die vorm van betekenisverklarings, maar soms ook vertaalekwivalente, koteksinligting en idiomatiese gebruik, asook vormkommentaar soos grammatiese inligting en uitspraakleiding. Ander inligting sluit lemmavergelyking, betekenisverandering en etimologiese inligting in. Baie van die inligting word by "eenigszins duistere of belangwekkende woorden" as opmerkings aangebied. Aangesien daar nog nie baie naslaanbronne oor Afrikaans was nie, het Mansvelt buiten taalkundige inligting ook inligting verskaf wat betrekking het “op 't eigenaardig karakter der Afrikaners of op hunne levenswijze en gebruiken, die mede hun eigen stempel op de volkstaal van dit zuidelijk werelddeel hebben afgedrukt" (Mansvelt 1884:v-vi; Gouws 1995:56; Schoonheim 1998:7).

Alhoewel Mansvelt se Idioticon voorafgegaan is deur A.N.E. Changuion se Proeve van Kaapsch Taaleigen wat agterin sy spraakkuns De Nederduitsche Taal in Zuid-Afrika Hersteld gepubliseer is en allerweë as die aanvang van die Afrikaanse leksikografie beskou word (Bosman 1931:29), is Mansvelt se woordeboek vir Boshoff (1926:311) van groter belang as dié van Changuion. Ploeger en Nienaber (in Van der Merwe 1971:xiii) beskou Idioticon as "die volledigste, noukeurigste en mees wetenskaplike" leksikografiese poging wat tot op daardie tydstip ten opsigte van Afrikaans onderneem is, wat dit volgens Gouws (1995:44) "die belangrikste leksikografiese bydrae uit die negentiende eeu" maak.

Die waarde van Idioticon is enersyds geleë in die wetenskaplike versorging en beredeneerde verklarings en etimologieë, maar andersyds in die metaleksikografiese baanbrekerswerk (Van der Merwe 1971:xiii; Gouws 1995:45). Hoewel Mansvelt vanuit 'n Nederlandse perspektief na Afrikaans gekyk het en daardeur meer by die Nederlandse leksikografie aangesluit het, verteenwoordig Idioticon die eerste selfstandige Afrikaanse woordeboek wat primêr gerig is op Afrikaanssprekendes wat in die studie van Afrikaans belang stel (Gouws 1995:48; Schoonheim 1998:43). Só wou Mansvelt met sy Idioticon, in teenstelling met sy tydgenote, dui op die eiesoortigheid van Afrikaans as onafhanklike taal naas Nederlands (Gouws 2003:79). Hy doen

3 Die Arts Department van Het Stellenbosch Gymnasium is in 1879 van die res van die skool afgeskei en in 1881 as 'n kollege van die Universiteit van die Kaap die Goeie Hoop erken. Die naam is later verander na die Stellenbosch College and College School (Du Toit \& Venter 1966:29, 31, 38; Kapp 2013:13, 23). 
dit reeds in die "Voorbericht" deur na Nederlands en Kaaps-Hollands as verskillende tale te verwys en ook te dui op die variëteitsverskille in Afrikaans (Mansvelt 1884:iii, vi; Gouws 1995:50). Sodoende het Mansvelt weggebreek van die tradisie van sy tyd en het hy 'n waardevolle bydrae tot die ontwikkeling van die Afrikaanse leksikografie gelewer ${ }^{4}$ (Gouws 1995:44).

Dat Idioticon wel "een van die hoekstene van ons Afrikaanse leksikografie" is en "'n belangrike basis geskep het vir die voortsetting van die verklarende Afrikaanse leksikografie", soos wat Boshoff (1926:312) en Gouws (1995:44) te kenne gee, blyk uit die invloed wat dit op leksikografiese bronne na dié van Mansvelt gehad het. Boshoff(1926:312-313) dui daarop dat byna alle Afrikaanse woordeboeke en woordelyste wat in die eerste dekades na die verskyning van Idioticon die lig gesien het direk of indirek daaruit geput het. Dit sluit die voorvegters vir Afrikaans, die Genootskap van Regte Afrikaners, se Patriotwoordeboek/Patriot Dictionary (1902/1904) in, wat in die "Foorberig" beken: "Oek het ons heel wat geput uit di ,Idioticon' fan Mnr. N. Mansvelt" (Du Toit 1902, in Van der Merwe 1968). Mansvelt se werk sou volgens Boshoff (1926:312) selfs neerslag vind in die leksikografiese bydraes van een van die prominentste voorstanders van die behoud van Nederlands aan die Kaap, W.J. Viljoen (sien 3.1). Dit het ook daartoe aanleiding gegee dat Afrikaans die aandag aangegryp het van Europese taalkundiges soos H. Schuchardt, J. te Winkel en D.C. Hesseling wat hulle hoofsaaklik begin besig hou het met teoretiese beskouinge oor die oorsprong van Afrikaans en Idioticon as belangrike bron beskou het om kennis oor die Afrikaanse woordeskat op te doen (Boshoff 1920:108; 1926:312; Van der Merwe 1968:Inleiding). Idioticon sou later die hoofbron ten opsigte van Afrikaans vir die Woordenboek der Nederlandsche Taal word, deurdat Mansvelt tot na sy terugkeer na Nederland as Suid-Afrikaanse skakel met dié woordeboek opgetree het (Boshoff 1926:312; Snijman 1964:3).

\section{DIE NEDERLANDS-AFRIKAANS-STRYD}

\subsection{Die pro-Nederlandse stryd: Viljoen en die VNS}

Alhoewel Mansvelt 'n positiewe grondslag vir die ontwikkeling van die Afrikaanse leksikografie in Stellenbosch gelê het, het 'n Afrikaanse bewussyn rondom die draai van die eeu nog op Stellenbosch ontbreek (Kapp 2013:14). In 1897 verskyn daar byvoorbeeld uit die pen van W.S. Logeman, Mansvelt se opvolger as dosent in moderne tale en geskiedenis aan die Victoria Kollege, ${ }^{5}$ 'n Leesboek en grammatika, met oefeningen en woordenlijst, Hollandsch-Engelsch en 'n jaar later Essentials of Dutch grammar. In die "Voorrede" tot die Leesboek en grammatika met sy Nederlands-Engelse woordelys, word daar na Nederlands as "onze moedertaal" verwys (Logeman 1897:v). Dat die bron in 'n bepaalde behoefte voorsien het, blyk daaruit dat dit tot $1907^{6}$ verskeie uitgawes beleef het.

Die pro-Afrikaanse gees wat met die stigting van die Genootskap van Regte Afrikaners (GRA) in 1875 in die Paarl posgevat het, het dus skynbaar nie tot in Stellenbosch oorgevloei nie (Kapp 2013:14). Inteendeel, daar het aan die einde van die negentiende eeu 'n pro-Nederlandse beweging op Stellenbosch posgevat waarvan die navolgers hulle vir die behoud en bevordering van

$4 \quad$ Vir 'n meer gedetailleerde oorsig oor die leksikografiese bydrae van Mansvelt se Idioticon, sien Gouws (1995).

$5 \quad$ In 1887 is die Stellenbosch College and College School ter ere van koningin Victoria se goue jubileum na Victoria Kollege herdoop en in 1899 het die skool finaal 'n aparte afdeling geword (Du Toit \& Venter 1966b:39; Kapp 2013:13, 23).

6 Die 1907-uitgawe van die Leesboek en grammatika is in die Vereenvoudigde Nederlands Spelling uitgegee. 
Nederlands beywer het (Malan 1963:174). Volgens Kapp (2009:12) was die voorstanders van Nederlands teen Afrikaans gekant omdat hulle dit nie as 'n taal van hoë ontwikkeling beskou het nie, aangesien Afrikaans nog oor geen grammatika of noemenswaardige letterkunde beskik het nie. Dit is ook as "platvloers" beskou omdat dit nie vir hoër funksies in die openbaar gebruik is nie (Kapp 2009:12).

Een van die vurigste voorstanders van Nederlands was W.J. Viljoen wat Logeman in 1895 opgevolg het (Nienaber 1968:1). Sy aanstelling het volgens Kapp (2013:17) sterk leierskap vir die Nederlandse strewe beteken. Alhoewel hy reeds as student 'n artikel gepubliseer het oor "De Taal in Zuid-Afrika" en in 1894 gepromoveer het met die proefskrif "Allgemeine Einleitung zur Geschichte der Cap-Hollandischen Sprache", 7 lewer hy in 1895 'n lesing voor die studente waarin hy 'n beroep op hulle doen om "beskaafde Nederlands" te praat. In 1895 stig hy die Nederlandse letterkundevereniging Ons Spreekuur en as bestuurslid van die Zuid-Afrikaansche Taalbond spreek hy hom sedert 1897 ten gunste van tradisionele Nederlands en Nederlandse waardes in Suid-Afrika uit (Bosman 1959:75; Kapp 2013:19).

Vanweë die toenemende teenstand wat Nederlands ondervind het as gevolg van die taal se ingewikkeldheid, het die Taalbond hulle sedert 1895 vir die vereenvoudiging van Nederlands beywer (Nienaber 1968:1; Claassen 1977:46-47). Hiermee word bedoel die "vereenvoudiging van spelling en van ondergeskikte grammatikale reëls, en die erkenning van tipies Afrikaanse woorde en uitdrukkinge", aldus Bosman (1959:75). By Het Eerste Congres ter Vereenvoudiging der Nederlandsche Taal wat op 4 en 5 Januarie 1897 in Kaapstad gehou is, is daar op 'n aantal voorstelle vir die vereenvoudiging van Nederlands ooreengekom wat aangesluit het by die poging wat in 1891 deur R.A. Kollewijn, F. Buitenrust Hettema en J.J. Salverda de Grave in Nederland aangewend is om die Nederlandse spelling te vereenvoudig. Die Taalbond kon egter nie die vereenvoudigingsvoorstelle deur die Nederlandse taaloutoriteite goedgekeur kry nie en met die uitbreek van die Suid-Afrikaanse Oorlog (1899-1902) is die planne eers op die lange baan geskuif (Bosman 1959:75; Malan 1963:174-175, 177, 249; Malan 1974:290; Claassen 1977:45, 53, 57-58).

Toe die Taalbond na die oorlog die stryd om Nederlands te vereenvoudig in alle erns hervat het, het W.J. Viljoen, nou dosent in Nederlands, op 7 Februarie 1903 opdrag van die hoofbestuur ontvang om voorstelle vir die vereenvoudiging van Nederlands aan die hand te doen. Sy voorstelle, waarin hy hom tot ' $n$ groot mate aan die Kollewijnse spelling hou, maar wat ook algemeen erkende woorde en uitdrukkings uit die Afrikaanse spreektaal bevat, is op 14 Maart 1903 deur die Taalbond aanvaar. Hierna is Viljoen die taak opgelê om die voorstelle deur die Nederlandse taalverenigings bekragtig te kry sodat dit onmiddellik in Suid-Afrika toegepas kon word. Na samesprekings en vergaderings met verskeie Nederlandse organisasies en taalgeleerdes het Viljoen op 5 Oktober 1903 'n verklaring van De Maatschappij der Nederlandsche Letterkunde te Leiden ontvang waarin sy voorstelle goedgekeur is. Nadat die voorstelle op 28 Desember 1904 met 'n oorweldigende meerderheid op 'n taalkonferensie in Kaapstad goedgekeur is, is dit in Suid-Afrika geïmplementeer (Malan 1963:177-178; Snijman 1964:7; Malan 1974:290; Claassen 1977:59-60, 63, 70, 73). Hierdie ortografiese sisteem sou voortaan as die Vereenvoudigde Nederlandse Spelling (VNS) bekend staan (Malan 1963:249).

In reaksie op 'n besluit wat tydens die vergadering van 1904 geneem is dat voorsiening gemaak moes word vir woordeboeke in die VNS, publiseer Viljoen saam met Hubertus Elffers in 1908 'n Beknopt Nederlands Woordeboek voor Zuid-Afrika in die VNS (Snijman 1963, in Gericke 1991a:109; Snijman 1964:7). Die doel van die lywige woordeboek van 1349 bladsye

\footnotetext{
$7 \quad$ Algemene inleiding tot die geskiedenis van die Kaap-Hollandse taal.
} 
wat ook heelwat Afrikaanse lemmas ingesluit het, was enersyds om Nederlands as spreektaal op Suid-Afrikaanse bodem te bevorder, maar andersyds "de zuivering van het Hollands hier te lande" (Elffers \& Viljoen 1908:Voorbericht; Snijman 1963, in Gericke 1991a:109; Snijman 1964:7). Dat die woordeboek uiteindelik nie in sy doel geslaag het nie, blyk daaruit dat dit geen herdrukke beleef het nie. Buitetekste sluit onder andere "Hoofdpunten van de vereenvoudigde schrijftaal" in, asook 'n lys van gebruiklike afkortings (Elffers \& Viljoen 1908).

Van dieselfde skrywers verskyn 'n paar maande later ook 'n tweetalige English-Dutch and Dutch-English Dictionary in die VNS (Gericke 1991a:109). Die woordeboek, waarvan die inhoud op die Beknopt Nederlands Woordeboek berus, geskied ook "in nakoming van een belofte, door ons aan het Taalkongres van 1904 gegeven, dat er voor de nodige woordeboeken in de vereenvoudigde spelling zou worden gezorgd"' (Elffers \& Viljoen 1914:Voorbericht). Buiten 'n Engels-Nederlandse deel van 578 bladsye en 'n Nederlands-Engelse deel wat 631 bladsye beslaan, bevat die woordeboek ook lyste met eie-, geografiese en historiese name in Engels en Nederlands, landbou- en botaniese name en terme in Latyn, Engels en Nederlands, asook sterk werkwoorde in Engels en sterk, onreëlmatige en gemengde werkwoorde in Nederlands. Die woordeboek was baie suksesvoller as sy voorganger deurdat dit tot en met 1920 nege heruitgawes beleef het. Die sukses is nie noodwendig te danke aan die sukses van die VNS nie, maar waarskynlik eerder aan 'n gebrek aan vertalende Afrikaans-Engelse woordeboeke - 'n behoefte waaraan eers in 1921 voldoen is met die verskyning van verskeie vertalende sakwoordeboeke (Snijman 1964:9).

\subsection{Die pro-Afrikaanse stryd: Smith en die ATV}

Die aanvaarding van die VNS het hewige reaksie onder die publiek ontlok (Claassen 1977:75). Maar anders as vóór die oorlog, was die kern van die pro-Afrikaanse beweging nou in Stellenbosch waar veral die studente die stryd aangesê het (Nienaber 1959:37). Onder hulle was Lydia van Niekerk wat vanaf 1919 tot 1930 dosent in Nederlands op Stellenbosch was. Die pro-Afrikaanse stryd is gelei deur 'n aantal oudstudente van die Victoria Kollege wat pas teruggekeer het uit Europa waar hulle hulle doktorsgrade verwerf het. Hulle stig op 3 November 1906 die Afrikaanse Taalvereniging (ATV) in Kaapstad en op 24 Oktober 1907 word 'n tak van die ATV ook op Stellenbosch gestig. Die stigting van die Stellenbosse ATV-tak het egter aanleiding gegee tot 'n heftige taalstryd tussen die dosente en studente van die Victoria Kollege. W.J. Viljoen het byvoorbeeld na die ATV verwys as die "Arme Taal-verknoeiers" en hulle "een slang in z'n boesem [sic]" genoem (Kapp 2013:21-22).

Die stryd is op die spits gedryf met D.F. Malan se toespraak "Het is ons ernst" wat hy tydens die ATV se kongres op 13 Augustus 1908 op Stellenbosch gelewer het (Bosman 1959:77; Kapp 2009:16). Hierin het hy die volgende oproep ten opsigte van Afrikaans gedoen (in Nienaber \& Heyl s.a.:99):

Verhef de Afrikaanse taal tot schrijftaal, maak haar de draagster van onze kultuur, van onze geschiedenis, onze nationale idealen, en gij verheft daarmede ook het volk, dat haar spreekt.

Op dieselfde kongres het Malan samewerking tussen die Taalbond en ATV in gemeenskaplike belang van Nederlands en Afrikaans bepleit (Bosman 1959:79; Nienaber 1968:2). Uiteindelik het die idee van een of ander oorkoepelende liggaam waarin die pro-Afrikaanse en pro-Nederlandse taalstryders kon verenig - die behoefte aan 'n "vereniging van verenigings", aldus Nienaber (1959:37) - wyd inslag begin vind. Daar is toenemend tot die besef gekom dat die NederlandsAfrikaans-taalsaak 'n saak was waar verdraagsaamheid, saamsnoering van kragte en eendragtige optrede nodig was, aldus Bosman (1959:79). En hiervoor was “'n sentrale, gesaghebbende, erkende liggaam nodig"; “'n liggaam wat verder die nodige leiding kon gee” (Bosman 1959:79). In reaksie 
op hierdie behoefte is die Suid-Afrikaanse Akademie vir Wetenskap en Kuns dan uiteindelik op 2 Julie 1909 gestig om die pro-Nederlandse en pro-Afrikaanse kragte te verenig in hulle stryd om die behoud van die Hollandse taal (dit is Nederlands én Afrikaans) in Suid-Afrika (Malan 1963:193).

In navolging van die versoening wat deur die stigting van die Akademie bewerkstellig is, nader die ATV se bestuur Viljoen se Ons Spreekuur in 1910 om 'n gesamentlike Studentetaalkonferensie op 6 en 7 April 1911 aan te bied (Kapp 2013:26). Die konferensie het hulle sterk ten gunste van die behoud van Nederlands uitgespreek, maar het beklemtoon dat Afrikaans dieselfde gebruik as Nederlands moes geniet en dat 'n universiteit gestig moes word waar Nederlands/Afrikaans as eksaminerende taal sou dien vir die bereiking van hierdie ideaal (Kapp 2013:28). 'n Jaar later verskyn die jaarboek van die Victoria Kollege vir die eerste keer as 'n tweetalige Engelse/Nederlandse blad en in 1913 stel die Waaksaamheidskommissie van die Kollege in die gees van die Taalkonferensie 'n manifes op waarin hulle stel dat Stellenbosch "sinds jaren innig verbonden [is] met het geestelike, zedelik en national leven van het Hollandssprekende gedeelte van het volk" (Kapp 2013:39).

In 1914 word J.J. Smith, een van die leidende studente van die Stellenbosse ATV en sedert 1915 nasionale voorsitter van die ATV, as professor in Frans en Duits aan die Victoria Kollege aangestel (Snijman 1964:11; Kapp 2013:27,36). Die toetrede van Smith en ander jong professore tot die dosentekorps het volgens Kapp (2013:37) 'n dinamiese karakter aan die Afrikaanse strewe gegee. Die Raad van die Victoria Kollege spreek in Februarie 1915 vir die eerste keer uitdruklik die wens uit dat "deze inrigting hare natuurlike bestemming kan bereiken as een echte HollandschAfrikaansche universiteit” (Kapp 2013:40). Nadat J.S. Marais $£ 100000$ vir die stigting van só 'n universiteit op Stellenbosch bewillig het, is die privaat wet op die Universiteit van Stellenbosch in 1916 deur die Parlement aanvaar en kom die Universiteit van Stellenbosch (voortaan US) amptelik op 1 April 1918 tot stand (Kapp 2013:41, 47). J.J. Smith, wat die Senaat reeds in 1916 oortuig het dat Afrikaans ook as onderrigtaal kan geld, is as die eerste voorsitter van die Senaat aangewys (Kapp 2013:41, 46). Hy spreek die studente in Junie 1920 toe en doen 'n beroep op hulle om "u ouers, $u$ vriende, u omgewing [te] oortuig dat 'n selfbewuste, selfstandige Afrikaanse volk sonder Stellenbosch nie moontlik is nie" (Kapp 2013:49).

Die studente was egter nie tevrede met net 'n Afrikaanse universiteit nie. Op 16 Augustus 1918 word die volgende mosie eenparig op 'n monstervergadering van die studente aangeneem:

Ons, die studente van die Universiteit van Stellenbosch, vra die Raad beleefdelik om ons wens tegemoet te kom en ons so spoedig moontlik aan 'n stoel in Afrikaans te help.

Hulle dui vervolgens op die belangrikheid van só 'n leerstoel in die stryd om die erkenning van Afrikaans en die uitbreiding van hulle taalregte in die hoër onderwys (Du Toit 1966:72-73). Nog in dieselfde jaar besluit die Universiteit om met ingang 1919 'n professoraat in Afrikaans in die lewe te roep. Die besluit is egter eers in 1920 uitgevoer toe die kampvegter vir Afrikaans, J.J. Smith, as eerste professor in Afrikaans aan die US benoem is. Die leerstoel in Afrikaans is uit die Jan Maraisfonds bekostig (Du Toit 1966:72, 75; Kotzé 1966:465). Na die instelling van die Jan Marais-leerstoel het die Raad van die Universiteit 'n spesiale komitee benoem om die verhouding tussen die leerstoele in Nederlands en Afrikaans, wat afsonderlik onder die afdeling Lettere in die Fakulteit Lettere en Wysbegeerte ressorteer het, te omskryf. Daar is uiteindelik besluit dat die twee leerstoele nie onafhanklik van mekaar sou staan nie, maar onderdele van dieselfde departement sou vorm. So is die Departement Nederlands en Afrikaans ${ }^{8}$ in 1922 in die lewe geroep (Du Toit 1966:72, 74-75).

8 Dat Afrikaans oor die verloop van jare 'n meer prominente rol in die Departement begin speel het, blyk daaruit dat die Departement se naam in 1952 verander is na die Departement Afrikaans-Nederlands en in 1979 na die Departement Afrikaans en Nederlands. Die Departement dra vandag steeds laasgenoemde naam en daar sal voortaan dienooreenkomstig na die Departement verwys word.

Tydskrif vir Geesteswetenskappe, Jaargang 56 No. 1: Maart 2016

doi.10.17159/2224-7912/2016/v56n1a16 
4. DIE ONTWIKKELING VAN DIE AFRIKAANSE WOORDELYS EN SPELREËLS ONDER DIE INVLOED VAN NEDERLANDS

\subsection{Voortgesette stryd}

In 1914 roep die nuut gestigte Suid-Afrikaanse Akademie vir Wetenskap en Kuns (sien 3.2) 'n Spellingkommissie in die lewe aan wie die taak opgelê is om spelreëls vir Afrikaans daar te stel. J.F.E. Celliers, wat later 'n dosent aan die US se Departement Afrikaans en Nederlands sou word, was 'n lid van die kommissie (Nienaber 1968:8; Eksteen 1985:170). Na die goedkeuring van die reëls op 18 September 1915 is daar besluit om ook 'n woordelys saam te stel. Hiervoor is 'n "Woordelijs-Kommissie" " benoem waarin onder andere J.J. Smith gedien het (Le Roux, Malherbe \& Smith 1917:iv-v, vii). In 1917 laat die kommissie die woordelys saam met die spelreëls van 1915, asook negentien aanvullende reëls, die lig sien as die eerste Afrikaanse woordelys en spelreëls (voortaan AWS) (Le Roux et al. 1917:v, xvii). Sedertdien het daar nog nege uitgawes van die $A W S$ verskyn: in 1918, 1921, 1931, 1937, 1953, 1964, 1991, 2002 en 2009 onderskeidelik.

Die $A W S$ is 'n standaardwerk vir Afrikaans wat deur baie Afrikaanssprekendes soos onderwysers, dosente en taalpraktisyns as 'n gesaghebbende en preskriptiewe naslaanwerk oor die spelling en skryfwyse van Afrikaans beskou word. Die woordeboek vir spesiale doeleindes, wat gereeld herbewerk word, se hoofdoel is leiding op die gebied van spelling en skryfwyse, standaardisering, normering en die beskrywing van die leksikon van Standaardafrikaans. Dié publikasie bestaan tradisioneel uit twee primêre afdelings, naamlik 'n spelreëlgedeelte wat fokus op die bereëling van die ortografiese konvensies van Standaardafrikaans, en 'n woordelysgedeelte wat meestal fokus op kontemporêre skriftelike, formele Standaardafrikaans (Kroes 1985:328; Morkel 2009:6; Swart 2009:6).

Die liggaam verantwoordelik vir die saamstel van die $A W S$ is die Taalkommissie van die Suid-Afrikaanse Akademie vir Wetenskap en Kuns. Sedert die eerste uitgawe in 1917 verskyn het, het daar tot en met die agste uitgawe van die $A W S$ wat in 1991 verskyn het deurlopend dosente verbonde aan die US se Departement Afrikaans en Nederlands op die Taalkommissie gedien. ${ }^{10}$ Dit is egter veral D.B. Bosman, J.J. Smith en E.C. Pienaar, almal voorheen verbonde aan die Departement, wat 'n prominente rol in die voortgesette Nederlands-Afrikaans-stryd gespeel het. ${ }^{11}$

9 Die kommissie het oor die jare verskillende benamings gehad. Met die 1921-uitgawe het dit as die Woordelys-Komitee en met die 1931-uitgawe as die Spelling-kommissie bekend gestaan. Sedert die vyfde uitgawe in 1937 is dit as die Taalkommissie bekend, soos wat dit vandag steeds bekend staan. Ten einde verwarring te voorkom, sal daar voortaan daarna verwys word as die Taalkommissie.

10 Tydens die politieke oorgang in Suid-Afrika aan die begin van die negentigerjare het drie Stellenbosse dosente wat op die Taalkommissie gedien het, naamlik Fritz Ponelis, Rufus Gouws en Leon de Stadler, in 1993/1994 as lede van óf die Taalkommissie óf die Akademie óf albei bedank omdat hulle gemeen het dat die Akademie geen verdere normeringsrol vir Afrikaans kon speel nie vanweë die feit dat dié liggaam geen geloofwaardigheid by bruin en swart Afrikaanssprekendes gehad het nie en dat die geantisipeerde Demokratiese Taalraad 'n groter kans op sukses gestaan het (Kapp 2009:142-143). Hierna het nog net een ander personeellid van die US se Departement Afrikaans en Nederlands op die Taalkommissie gedien, naamlik Ilse Feinauer. Sy het egter nog voor die verskyning van die negende uitgawe van die $A W S$ uit die Taalkommissie bedank en sedertdien het daar nog nie weer 'n personeellid van hierdie departement op die Taalkommissie gedien nie.

11 Behalwe vir hierdie drie persone, word daar nie spesifiek na ander US-dosente se rol in die NederlandsAfrikaans-stryd verwys nie, aangesien dit nie moontlik is om spesifieke Taalkommissiebesluite aan spesifieke Taalkommissielede te verbind nie. Ter wille van volledigheid en die feit dat die NederlandsAfrikaans-stryd 'n blywende invloed op die $A W S$ uitgeoefen het, word die Nederlandse invloed op al tien uitgawes van die $A W S$ egter bespreek. 
Met die Nederlands-Afrikaans-stryd wat aanleiding gegee het tot die stigting van die Akademie nog vars in hulle geheue (sien 3.2), het die eerste Spellingkommissie van 1914 besluit om die nuwe spellingsisteem enersyds op ' $n$ fonetiese grondslag te laat berus, maar andersyds die band met Nederlands te handhaaf deur nie onnodig van die VNS af te wyk nie (Le Roux 1926:272; Malan 1963:200). Dat die band tussen Nederlands en Afrikaans ook vir die opstellers van die 1917-AWS, waarvan J.J. Smith deel uitgemaak het, van besondere belang was, blyk reeds uit die voorwoord waarin daar gemeld word dat "Hollands [...] die onmisbare bron [is] waaruit Afrikaans moet put, oral waar voorlopig nie deur eie taalmiddels in die behoeftes kan voorsien word nie" (Le Roux et al. 1917:iv). Daarom is dit as een van die vyf grondbeginsels van die Afrikaanse spelling gestel dat daar so min as moontlik van die VNS afgewyk word (Le Roux et al. 1917:ix). Die grondbeginsel is vir die volgende ses uitgawes (tot en met die 1953-uitgawe) grootliks onveranderd gelaat (Le Roux, Malherbe \& Smith 1918:ix; Bosman et al. 1921:vii; Boshoff et al. 1931:viii; 1937:vii; 1953:6). In die 1964-uitgawe word die VNS egter nie meer as uitgangspunt geneem nie, maar word daar rekening gehou "met die spelling wat vandag amptelik in Nederland erken word" (Taalkommissie 1964:1). Die herformulering doen egter vreemd aan, aangesien die Afrikaanse ortografie in 1964 weinig of niks te make gehad het met die spelling wat op daardie stadium in Nederland gebruik is nie. Wat die grondbeginsels betref, is daar eers met die 1991-uitgawe enigermate met Nederlands gebreek deurdat daar nou bloot verwys is na die "tradisie waarvolgens Standaardafrikaans gespel en geskryf word"12 (Taalkommissie 1991:11). McLachlan (2012:25) dui daarop dat die grondbeginsels in wese onveranderd gebly het oor die tien uitgawes heen. Dit beteken dat (historiese) Nederlands steeds tot ' $n$ groot mate as rigsnoer vir die Afrikaanse spelling dien. Dit kan gesien word uit verskeie Nederlandse vorme wat oor die afgelope dekades in die Afrikaanse ortografie bestendig is, soos die behoud van die $v$ naas die $f$ en die ei naas die $y$ (Eksteen 1985:185-186).

Die Afrikaanse spelling se besondere band met Nederlands blyk verder uit die deurlopende verwysing na en vergelyking met Nederlands wat in die spelreëls in die 1917-uitgawe van die Afrikaanse woordelys en spelreëls voorkom. Daar word in die spelreëls sewe keer die woorde "net soos in die V.H.S." ${ }^{13}$ aangetref. ${ }^{14}$ Om een taal se spelreëls op te stel met die prinsipiële inagneming van die spelling van 'n ander taal, is volgens Combrink (1991a:13) egter taalkundig onverdedigbaar en dit was dus hoogstens 'n propagandistiese invalshoek. Die Nederlandse invloed op die Taalkommissiespelling van 1917 kan ook duidelik gesien word in die handhawing van die Nederlandse $i j$ (byvoorbeeld pijn, lij en belangrijk), $y$ en au en $c$ in vreemde woorde (byvoorbeeld hypothese, automaties en café), die stom -w (byvoorbeeld vrouw), mijn, sijn, jouw en $u w$ as besitlike voornaamwoorde, en $s$ 'n as genitiefvorm, $i k$ as swakbeklemtoonde vorm naas die beklemtoonde vorm van die persoonlike voornaamwoord $e k$, en $a i$ in woorde van vreemde oorsprong om die [æ:]-klank voor te stel (byvoorbeeld populair) (Van der Merwe 1968:101; Le Roux et al. 1917:ix-xx).

Die omvattende invloed van Nederlands op Afrikaans blyk verder uit die grootskaalse adleksifisering $^{15}$ van Afrikaans uit Nederlands soos waargeneem in die woordelys van die 1917-

12 Tog word daar nog op dieselfde bladsy gemeld dat "die Afrikaanse spelling [...] by dié van Nederlands [aansluit]" (Taalkommissie 1991:11).

13 Vereenvoudigde Hollandse Spelling, soos wat die Vereenvoudigde Nederlandse Spelling vroeër bekend gestaan het.

14 Vergelyk Le Roux, Malherbe \& Smith (1917) p. xi, reël 6 en 8, p. xii, reël 15, p. xiii, reël 18, p. xiv, reël 24, p. xvii, reël 3, en p. xviii, reël 8.

15 Adleksifisering, ook bekend as kulturele ontlening (Grant 2015:435), is wanneer leksikale items aan die leksikon toegevoeg word om 'n toevallige of kulturele gaping in die leksikon te oorbrug (Stolberg 2015:63). 
AWS. Die volgende is slegs enkele voorbeelde hiervan: auto, bigot, different, door- in woorde soos doorgaans, editeur, edukasie, felisiteer, goevernement, humaan, indigestie, introduseer, kapabel, leeuwin, pardon, rekommandeer, relaksasie, telefoneer, tutoyeer, vanille-ijs, vlees of vleis (as sinonieme) en vleuelpiano (Le Roux et al. 1917). In enkele gevalle het die Taalkommissie egter 'n groter mate van verafrikaansing nagestreef (vergelyk die Taalkommissie se nuws teenoor nieuws van VNS en ATV-spelling en verafrikaanste woorde soos spiets).

Aan die begin van 1920 het die Taalkommissie 'n aantal wysigings aan die Afrikaanse spelling goedgekeur wat tot 'n groot mate 'n breuk met die Nederlandse spelling verteenwoordig het (Smith 1920a:329; 1920b:295). Dit sluit onder andere in die vervanging van $i j$ met $y$ en $u w$ met $u u$ (byvoorbeeld my in plaas van mij en nuus in plaas van nuws), die weglating van die stom $-w$ (byvoorbeeld vrou in plaas van vrouw), die wegval van $i k$ as persoonlike voornaamwoord en myn en syn as besitlike voornaamwoorde (met ander woorde slegs $e k, m y$ en sy word as voornaamwoorde gebruik), en die afskaffing van talle vreemde spelvorme ten gunste van die grootskaalse verafrikaansing van vreemde woorde, byvoorbeeld ai word $\hat{e}$ (populêr in plaas van populair), au word ou (outeur in plaas van auteur), $c$ word $k$ of $s$ waar dit onderskeidelik as [k] en [s] uitgespreek word (konjak in plaas van conjak en sentrum in plaas van centrum), ch word $g, k, s, s j$ of $t j$ waar dit onderskeidelik as [x], [k], [s], [J] of [t]] uitgespreek word (gemie, kolera, masien, sjokolade en tjek), eau word o (buro in plaas van bureau), ensovoorts (Smith 1920a:329). Die wysigings het egter aanleiding gegee tot groot teenkanting van verskeie Transvaalse koerante, onder leiding van Gustav S. Preller, asook 'n aantal Transvaalse onderwysers, wat 'n meer Nederlandse ortografie vir Afrikaans voorgestaan het (Smith 1920b:295; sien "Protes teen spelling-wysiging" 1920:3 vir 'n volledige uiteensetting van die besware). Aangesien die wysigings egter reeds deur die SuidAfrikaanse Akademie vir Wetenskap en Kuns goedgekeur is, het die Taalkommissie nie verder daarop ingegaan nie ("Protes teen spelling-wysiging" 1920:3).

As gevolg van die besluit deur die Taalkommissie, waarby die dosent in Nederlands aan die US se Departement Afrikaans en Nederlands, D.B. Bosman, hom intussen aangesluit het, is heelwat van die nederlandistiese vorme wat nog in die eerste twee uitgawes van die $A W S$ voorgekom het opmerklik afwesig in die 1921-uitgawe (Eksteen 1985:172). Die wegbeweging van die sterk Nederlandse invloed is ook in die woordelys te bespeur. 'n Aantal Nederlandse lemmas is uit die woordelys geskrap (byvoorbeeld auto, bigot, woorde met door-, edukasie, eksepsie, relaksasie en tutoyeer) en baie van die woorde wat 'n meer Nederlandse vorm gehad het, is in ooreenstemming met die veranderde spelreëls 'n meer verafrikaanste vorm in ooreenstemming met die Afrikaanse uitspraak gegee. In woorde soos envelop, eventueel en privilegie is die $v$ byvoorbeeld deur ' $\mathrm{n} w$ vervang sodat dit nou enwelop, ewentueel en priwilegie was. Ander spellingveranderinge in ooreenstemming met die Afrikaanse uitspraak sluit in gevanklik (was gevankelik), goewerment (was goevernement), kampanjie (was kampanje), moestas (was moustache) en plousiebel (was plausibel) (Bosman et al. 1921).

In 1926 steek die Nederlands-Afrikaans-stryd weer kop uit toe die Suid-Afrikaanse Onderwysersunie (SAOU) 'n aantal spellingveranderinge aan die Taalkommissie voorlê waarin hulle hulle ten gunste van 'n meer fonetiese spelling vir Afrikaans uitspreek. Die SAOU se voorstelle het behels dat ei oral deur $y$ vervang word (vergelyk pyl en peil, vyl en opveil, ensovoorts) en $v$ oral deur $f$ vervang word waar dit as [f] uitgespreek word, behalwe in eiename, en dat $d$ en $b$ as slotkonsonante deur $t$ en $p$ vervang word, sodat daar eerder fan en ferfanging geskryf word as van en vervanging, asook hont, rip, ensovoorts. Hulle het ook voorgestel dat die reël wat bepaal dat sommige woorde met die uitgang -lik gespel word en sommige -elik, verander word sodat óf slegs een uitgang in alle gevalle gebruik word, óf albei vorme deurgaans gebruik kan word (byvoorbeeld duidelik of duidlik). Ten slotte was die SAOU ook van mening dat die spelling 
aansienlik vergemaklik sou word indien die reël wat bepaal dat 'n konsonant wat op 'n kort, onbeklemtoonde vokaal volg nie verdubbel word nie (Bosman et al. 1921:xv, reël 37), konsekwent deurgevoer word sodat daar geskryf word bobejaan, klasiek, komissie, papegaai, ensovoorts (Malherbe 1926:108-109; "Nuwe spellingvoorstelle" 1926:4). In reaksie hierop het die Taalkommissie 'n verslag met spellingvoorstelle vrygestel wat hulle vir wyer bespreking onder die aandag van die publiek wou bring (Malherbe 1926:108).

Uit die reaksies wat gevolg het, is dit duidelik dat daar steeds 'n taalstryd tussen die voorstanders van Nederlands en die voorstanders van Afrikaans bestaan het, aangesien die onderskeie artikels en briewe wat daaroor in die pers verskyn het dit veral gehad het oor die insluiting van Nederlands, al dan nie, by die Afrikaanse spelling. Die pro-Nederlandse faksie is weer aangevoer deur Preller (1926:4) wat die Taalkommissie daarvan beskuldig het dat hulle geen aandag gegee het aan die ontwikkeling van Afrikaans in 'n meer behoudende sin onder die invloed van Nederlands in Transvaal nie, maar dat almal nou meestal Afrikaans moes skryf soos dit in die Kaapprovinsie gepraat word, deurdat die "platste" vorm van 'n woord dikwels as die "eg Afrikaanse" vorm gekies is terwyl enige ander vorm bloot as Nederlands afgemaak is. Hierdie beskuldiging eggo 'n kwessie wat reeds met die eerste uitgawe van die $A W S$ geopper is, naamlik dat die Taalkommissie nie verteenwoordigend genoeg was van die totale Afrikaanse spraakgemeenskap nie (Grosskopf 1917:7). Die feit dat al die lede van die Taalkommissie uit die Kaapse wynlanddistrik afkomstig was, het volgens Grosskopf(1917:7) veroorsaak dat baie woorde wat deur die Transvalers en Vrystaters gebruik is nie die $A W S$ gehaal het nie. Ook L.W. Hiemstra (1918:1-2) was van mening dat baie woorde in die eerste $A W S$ opgeneem is wat vir die Transvalers ongewoon of selfs plat voorgekom het. Hy het ook hierdie tekortkoming voor die deur van 'n kommissie gelê wat oorspronklik afkomstig is "uit 'n hoekie van die Westelike Provinsie" (Hiemstra 1918:1-2). Hierdie kritiek dui daarop dat die wegbeweging van Nederlands in die rigting van die verafrikaansing van die spelling (ten minste deels) toegeskryf kan word aan die dosente van die US se Departement Afrikaans en Nederlands se betrokkenheid by die Taalkommissie.

In reaksie op die heftige teenstand teen die spellingwysigings wat deur die SAOU voorgestel is, het die Unie uiteindelik amptelik hulle voorstelle teruggetrek en die Taalkommissie het nie verder daarop ingegaan nie (Preller 1926:4; "Nuwe spellingvoorstelle" 1926:4). Maar nog was dit nie die einde van Preller se Nederlandse veldtog nie. Saam met ander Transvaalse joernaliste en skrywers het hy hom in 1927 vir die hervorming van die Afrikaanse spelling in die rigting van Nederlands beywer ten einde teenstand teen die invloed van Engels te bied (Steyn 1987:209, 211). Preller, S.P. Engelbrecht en J. van Bruggen het na samesprekings met die Taalkommissie 'n afsonderlike verslag aan die Akademieraad gestuur waarin hulle 'n hele aantal ingrypende aanbevelings ten opsigte van die Afrikaanse ortografie ten gunste van 'n meer Nederlandse karakter gemaak het. Dit sluit onder andere in die herinvoer van die imperfektum, refleksief (byvoorbeeld sig), intervokaliese verbuiging van adjektiewe en vervoeging van die werkwoord, die uitskakeling van wisselvorme en anglisismes, en die gebruik van die woorde na en naar in verskillende semantiese kontekste ("Hersien spelling van Afrikaans" 1928:7; "Spellingveranderings in Afr." 1928:7; Steyn 1987:209, 216-217).

Die Taalkommissie het op hulle beurt vir Bosman en nog 'n dosent in Nederlands aan die US se Departement Afrikaans en Nederlands, E.C. Pienaar, aangestel om die verslag na te gaan en hulle opmerkings daaroor op te stel. Ten spyte van Bosman en Pienaar se hoedanigheid as dosente in Nederlands, was hulle gekant teen die oormatige vernederlandsing van Afrikaans soos voorgestel in die Prellerverslag. In reaksie hierop het die Akademieraad geweier om die Prellerverslag voor hulle algemene jaarvergadering van 1928 te laat dien en hiermee is Preller-hulle se hervormingsplanne die nekslag toegedien ("Spellingveranderings in Afr." 1928:7; Steyn 1987:219-220). 
Sodoende het die Stellenbosse kollegas Bosman en Pienaar 'n belangrike rol gespeel in die Akademie se beslissende stap om die Afrikaanse spelling teen die oormatige invloed van Nederlands te verskans.

Juis daarom is dit verbasend dat Bosman en Pienaar se kollega wat Afrikaans doseer het, J.J. Smith, wat intussen met werk aan die Woordeboek van die Afrikaanse Taal (voortaan WAT) begin het, die Nederlandse stryd verder sou voer. Gegewe Smith se betrokkenheid by die pro-Afrikaanse beweging, val dit vreemd op dat hy sedert die begin van sy samewerking met die Taalkommissie in 1917 altyd 'n voorstander van die meer konserwatiewe of Nederlandse vorm was waar daar 'n keuse tussen verskillende vorme van 'n woord bestaan het, aangesien hy van mening was dat 'n suiwer fonetiese spelvorm nie prakties haalbaar was nie. 'n Noue verwantskap met Nederlands was vir hom van groot kulturele belang vir Afrikaanssprekendes, soos dat dit die lees en studeer van Nederlands vir Afrikaanssprekendes sou vergemaklik sodat hulle Nederlandse hand- en studieboeke moeiteloos kon gebruik ("Geen nuwe spelling beoog nie" 1930:11; "Prof. J.J. Smith oor fonetiese spelling" 1930:1).

Smith se voorkeur vir die Nederlandse spelvorm het in 1930 aanleiding gegee tot 'n heftige spellingstryd tussen hom en die Taalkommissie, waarvan hy nog kort tevore lid was (Bosman 1959:120). Die Taalkommissie, waarvan Bosman steeds lid was en wat intussen aandag geskenk het aan die spellingbereëling van vreemde woorde, het grootliks 'n verafrikaansingsbeleid gevolg waarin groter voorsiening gemaak is vir wisselvorme. Smith kon hom egter nie met die verafrikaansingsbeleid van die Taalkommissie vereenselwig nie en het besluit om vreemde woorde in die WAT op 'n meer konserwatiewe wyse, nader aan die VNS, te skryf. (Malan 1974:292; Sien "Geen nuwe spelling beoog nie" 1930:11 vir 'n volledige uiteensetting van Smith se standpunt.)

Smith se voorstelle het aanleiding gegee "tot 'n opskudding in ons dagbladpers wat amper kan gelykgestel word met die opskudding veroorsaak by die uitbreek van 'n groot oorlog of by die uitslag van 'n algemene parlementaire [sic] verkiesing" ("Geen nuwe spelling beoog nie" 1930:11). Só fel was die stryd dat minister D.F. Malan besluit het om in te gryp deur 'n konferensie byeen te roep om die twis tussen Smith en die Akademie se Taalkommissie oor die spelling van vreemde woorde te besleg (Bosman 1959:120; Malan 1963:206; 1974:292). Die konferensie het op 27 en 28 Augustus 1930 in Pretoria plaasgevind (Malan 1963:206; 1974:292). Die uiteinde van die konferensie was dat daar oor die algemeen teruggekeer is na 'n meer konserwatiewe, Nederlandse vorm wat betref die spelling van sogenaamde vreemde woorde en eiename, alhoewel daar in baie gevalle ook 'n verafrikaanste vorm naas die Nederlandse vorm aangegee sou word. Alhoewel toegewings deur beide Smith en die Taalkommissie gemaak is, het die konferensie geen bindende gesag gehad nie, sodat nóg Smith, nóg die Taalkommissie verplig was om hulle aan die besluite van die konferensie te hou. (Malan 1974:292; Sien "Spelling-vergelyk word bekend gemaak" 1930:7, 9 vir die amptelike verklaring wat na afloop van die konferensie uitgereik is.) In werklikheid is daar dus geen "ooreenkoms" op die konferensie bereik nie, maar daar het bloot 'n verdere kloof tussen die spelling van die Taalkommissie en die WAT ontwikkel (Malan 1974:292).

Dat die 1931-uitgawe van die $A W S$ tot 'n mate 'n kniebuiging in die rigting van Smith se meer Nederlandse inslag ten opsigte van die Afrikaanse ortografie was, blyk uit die mate waartoe daar in die loop van die spelreëls nog na die VNS verwys word, asook die mate waartoe die Afrikaanse reëls ten opsigte van die Nederlandse ortografie geformuleer is. ${ }^{16}$ Die volgende spelreëlveranderinge is aangebring wat aan die Afrikaanse ortografie weer 'n meer Nederlandse karakter gegee het (Boshoff et al. 1931:xx-xxi, xxvi, xxxi; Malherbe 1931:4):

16 Vergelyk Boshoff et al. (1931) p. xviii, reël 3(a) en reël 6(b), opm. 2, p. xxii, reël 11 en 12, p. xxv, reël 18(b), p. xxix, reël 34, p. xxx, reël 37(b), en p. xxxii, reël 41(b). 
- $\quad i$ is behou in oop lettergrepe en eindlettergrepe van ongebruiklike vreemde woorde en gebruiklike woorde van vreemde oorsprong wat uitgaan op - $a,-c i$ (mv.), -i, -ibel, -ide, -idies, -ine, -inies, -itis, -o, -on, -us, -um, ensovoorts, soos fisika, botanici, vermicelli, indisponibel, piramide, hibridies, marine, aktinies, appendicitis, merino, bison, spiritus en minimum.

- Woorde wat vroeër net met ou-gespel is, kan nou ook met $a u$-gespel word, byvoorbeeld outeur of auteur.

- Die gebruik van $v / w$ word nie meer bepaal deur die aksent van 'n woord nie. In 'n hele aantal gevalle word beide $v$ en $w$ nou toegelaat, byvoorbeeld revolusie en rewolusie.

- In 'n sekere groep woorde word $x$ naas $k s$ toegelaat, byvoorbeeld exodus of eksodus.

- Waar $c h$ meer as een uitspraak toelaat ([x] of [k]), word nou net $c h$ erken, byvoorbeeld chemie.

- In 'n paar woorde wat as betreklik vreemd geld, word $c$ naas $s$ erken, byvoorbeeld cellulose of sellulose.

- Woorde waarvan die meervoud vroeër verafrikaans is, soos historisie, behou nou eerder hulle Latynse vorm (historici).

In 'n poging om aan die ooreenkoms van die spellingkonferensie te voldoen, het die Taalkommissie meer wisselspellings in die woordelys opgeneem ten einde erkenning te gee aan meer Nederlandse spelvorme, veral wat betref $a u / o u, t h / t, v / w$, en $x / k s$ (Boshoff et al. 1931:vii). Verder is die woordelys weer uitgebrei met die insluiting van heelwat woorde van Nederlandse afkoms, soos affidavit, autochthoon, demon, detachement, fok (teel), gesusters, interrogasie, kasueel, keuken, konfessie, konfirmasie, malisieus, mediateur en moedervlek, om maar enkele voorbeelde te noem (Boshoff et al. 1931).

Die verskyning van die 1931-uitgawe van die $A W S$ het egter nie 'n end gemaak aan die stryd oor die spelling van vreemde woorde nie. In 'n poging om 'n einde aan die spellingonenigheid te maak, word 'n tweede konferensie van 4 tot 6 Januarie 1932 op Stellenbosch gehou. Smith het in sekere gevalle ingewillig om die Taalkommissie se meer verafrikaanste spelvorme te aanvaar, terwyl die Taalkommissie toegewings in die rigting van groter vernederlandsing gemaak het deur byvoorbeeld au, eau, sc- (uitgespreek [s]), -ice, g (uitgespreek [3], [S] en [s]), gn, th en $z$ in sekere woorde te behou (byvoorbeeld restaurant, trousseau, scenario, executrice, regiment, korrigeer, genre, magnifiek, anthrax en zymose) en ai, au, c, ch en $x$ as wisselvorme naas die verafrikaanste vorme $\hat{e}, o u, k$ of $s, g$ en $k s$ te gee (byvoorbeeld affaire naas affêre, pause naas pouse, discipel naas dissipel, echo naas eggo, en axioma naas aksioma). (Kapp 2009:122; Sien "Die spellingooreenkoms" 1932:35 vir 'n volledige verslag van die besluite wat in verband met die spelling van vreemde woorde geneem is.) Ten einde die verwarring oor die Afrikaanse ortografie wat nou geheers het uit die weg te probeer ruim, het die Nasionale Pers in oorleg met Bosman nog in dieselfde jaar 'n brosjure met 'n Lys van wysiginge gepubliseer (Malan 1963:209).

In werklikheid het ook dié spellingkonferensie tot groter skeiding tussen die ortografiese sisteme van die $A W S$ en die WAT gelei (Malan 1963:208; 1974:292). Smith se spelwyse het egter al hoe meer die wind van voor gekry en steun daarvoor het vinnig begin kwyn (Gericke 1991b:47; Kapp 2009:122). Die nuwe Minister van Binnelandse sake, J.H. Hofmeyr, wat Malan in 1933 opgevolg het, het hom ten gunste van die Taalkommissie se spelwyse en téén Smith s'n uitgespreek en opdrag gegee dat die staatsvertaler en universiteite voortaan die spelreëls soos uiteengesit in die 1931-uitgawe van die $A W S$, en gewysig ingevolge die besluite van die spellingkonferensie op Stellenbosch, moes volg en dat die verafrikaanste vorme in die geval van wisselvorme telkens gekies moes word. Selfs die US (die tuiste van Smith en die WAT) het besluit om die Taalkommissiespelling te volg ("Minister gryp in in spellingkwessie" 1933:1; Gericke 1991b:47). 


\subsection{Geleidelike losmaking van Nederlandse invloed}

In die volgende uitgawes van die $A W S$ het die Taalkommissie enigermate probeer om weer 'n groter mate van verafrikaansing na te streef. So is daar in die 1937-uitgawe van die AWS gemeld dat, waar 'n keuse tussen twee spelvorme gelaat word ('n vreemde en verafrikaanste spelvorm), die voorkeur gegee moes word aan die verafrikaanste vorm (Boshoff et al. 1937:iv, xv). In die 1953-uitgawe is die aantal wisselvorme met 'n vreemde naas 'n verafrikaanste vorm eweneens verminder, maar in 'n aantal gevalle is albei vorme behou, veral by meervoudsvorme van vreemde woorde waar die vreemde en verafrikaanste spelvorm aanvaar word (Boshoff et al. 1953:8-9).

Wanneer die hoofstuk oor "Vreemde woorde" in oënskou geneem word, word dit duidelik dat die rede waarom die wisselvorme in die groep vreemde versus verafrikaanste spelvorm so drasties verminder kon word, daaraan toe te skryf is dat daar oor die algemeen 'n verskuiwing in die rigting van verafrikaansing van vreemde woorde plaasgevind het sedert die vorige uitgawe van die $A W S$. Sedert die vierde uitgawe het dit geblyk dat, waar die skrywende publiek voor 'n keuse van die vreemde spelvorm teenoor die verafrikaanste spelvorm van 'n woord geplaas is, die meeste mense telkens die verafrikaanste vorm gekies het. In die 1953-AWS is talle van die wildvreemde woorde óf geskrap, óf geheel verafrikaans, en in die tussenklas het die publiek telkens voorkeur gegee aan die Afrikaanse spelvorm, wat beteken dat baie van die woorde wat eers deel was van laasgenoemde klasse in hierdie uitgawe deel uitmaak van die eerste klas, dit is woorde wat volgens die gewone Afrikaanse spelreëls geskryf word (Boshoff et al. 1953:2, 10-11). 'n Spelreël wat egter volgens die redaksie van Die Brandwag nog baie probleme opgelewer het omdat dit op die historiese beginsel, met ander woorde Nederlands, geskoei is en daar nog nie 'n formule gevind is wat al die gevalle dek nie, is die gebruik van -de of -te by die attributiewe voltooide deelwoord, veral by werkwoorde wat op $-s$ eindig (“Afrikaanse woordelys" 1953:55).

Die Taalkommissie het in die 1964-uitgawe nog verder as voorheen gegaan met die verafrikaansing van die spelling van woorde van vreemde herkoms. Dit sluit in verskeie skeikundige terme wat in Engels met $q u$ - begin wat om etimologiese redes nou van $c h$ - na $k$-verander is (byvoorbeeld chinaldien word kinaldien) (Taalkommissie 1964:"Voorwoord", no. 6). Die reëls in verband met wisselvorme by die agtervoegsels -(e)elik(s), -(e)ling(s), -(e)loos, -(e)nis, en -(e)rig is nou ook met Afrikaans in plaas van Nederlands as uitgangspunt geformuleer (Taalkommissie 1964:"Voorwoord", no. 9). Dieselfde geld die 2002-AWS waar daar voorkeurvorme gegee is by bepaalde natuurwetenskaplike terme met die agtervoegsels -ied naas -ide (byvoorbeeld aldehied naas aldehide) en -ien naas -ine (byvoorbeeld aspirien naas aspirine) (eersgenoemde vorm geniet telkens voorkeur; Taalkommissie 2002:197, Reël 17.20). Laasgenoemde reël dui eweneens op groter verafrikaansing.

Daar is voortgegaan om lemmas met 'n sterk Nederlandse vorm uit die woordelys te skrap, soos autochthoon, edukasie, geloofbaar, keuken en moedervlek in die 1953-uitgawe (Boshoff et al. 1953), en envelop, fok (teel), gesusters, gevanklik, impressief, kado, leuterkous, onpassabel, nurks, uitentreure, urgent, verbrui, vermaagskap, vlied, vrydom, wied, en wig (ww.), en uitdrukkings soos aan die beterhand, na beliewe, deser dae, ten faveure van, vir waarde genote, na luid van en met referte tot in die 1991-uitgawe (Combrink 1991b:13-19; 1991c:7). Sedert die 1953-uitgawe word daar ook 'n onderskeid gemaak tussen vlees en vleis deurdat daar nou aangedui word dat vlees meestal figuurlik gebruik word (Boshoff et al. 1953:278).

Sommige woorde wat aanvanklik via Nederlands die Afrikaanse woordeskat binnegekom het, het oor die jare onder die invloed van Engels ' $n$ ander betekenis aangeneem as wat dit oorspronklik gehad het. In die 2002-uitgawe is daar dan ook erkenning gegee aan nuwe homoniemvorme wat in Afrikaans ontwikkel het, byvoorbeeld braaf kan nou naas goed ook 
dapper beteken en eventueel kan nou naas moontlik ook uiteindelik beteken, terwyl 'n mens ook nou iets in gemeen kan hê met iemand anders (Taalkommissie 2002:237, 267, 278). In ooreenkoms met die spelreëls is slegs die voorkeurvorme by wisselvorme van natuurwetenskaplike terme met die agtervoegsels -ied naas -ide en -ien naas -ine opgeneem, met ander woorde net die vorme met -ied en -ien vir die enkelvoudsvorm en -iede en -iene vir die meervoudsvorm is in die 2002-woordelys opgeneem (Taalkommissie 2002:209).

\subsection{Die nadraai}

Die Taalkommissie van die Suid-Afrikaanse Akademie vir Wetenskap en Kuns het deur die publikasie van die woordeboek vir spesiale doeleindes, die Afrikaanse woordelys en spelreëls, ongetwyfeld 'n taalgesag daargestel waardeur die standaardisering van die Afrikaanse ortografie en woordeskat bespoedig is en sodoende ' $n$ belangrike rol gespeel in die ontwikkeling van Afrikaans (Odendal 1984:192-193; Gouws \& Ponelis 1992:31, 34). Sedert sy verskyning in 1917 het die $A W S$ 'n betekenisvolle rol in die spellingbereëling van Afrikaans gespeel en daardeur in die dringende behoefte aan reëlmaat en orde in die Afrikaanse ortografie voorsien ("Uit ons eie boekrak" 1954:29, 31). Verskeie dosente verbonde aan die US se Departement Afrikaans en Nederlands, waaronder W. Kempen, M. de Villiers, F.A. Ponelis, J.G.H. Combrink en R.H. Gouws, het oor die jare, in hulle hoedanigheid as Taalkommissielede, hieraan meegewerk.

Die Nederlands-Afrikaans-stryd wat hom ook binne die US se Departement Afrikaans en Nederlands afgespeel het, het egter 'n merkbare invloed op die AWS uitgeoefen. Toe die Taalkommissie se ortografiese sisteem die lig gesien het in 1917, was dit duidelik dat die Afrikaanse ortografie 'n kompromis tussen die voorstanders van Nederlands en die voorstanders van Afrikaans was, aangesien daar nóú by die Nederlandse ortografie aangesluit is. Veral J.J. Smith sou in die eerste paar dekades na die verskyning van die $A W S$ hierin 'n prominente rol speel. Die band met Nederlands waarop hy met die samestelling van die WAT aangedring het, sou oor die volgende sowat nege dekades 'n blywende invloed op die Afrikaanse ortografie uitoefen. Ten spyte van ander Stellenbosse dosente soos Bosman en Pienaar se pogings om die Afrikaanse spelling van sy Nederlandse verlede te bevry, is die Nederlandse aspek oor die jare telkens na vore gestoot om die paar gevalle te verantwoord waarby daar nie uitgegaan is van die vorme wat konsekwent eenders gespel behoort te word nie (Eksteen 1985:185).

Alhoewel die hegte inskakeling by Nederlands aanvanklik nog opvallend aanwesig was, was daar egter mettertyd 'n geleidelike losmaak van die Nederlands georiënteerde spelwyse in die rigting van verafrikaansing (Eksteen 1985:171, 180). Op sekere momente in die ortografiese geskiedenis van Afrikaans was dit juis die Taalkommissie se besliste leiding in die rigting van groter verafrikaansing wat daartoe bygedra het om die Afrikaanse spelling los te maak van Nederlandse invloed. Ofskoon 'n groot hoeveelheid van die Nederlandse ballas afgeskud is, is daar egter nog spellinggebruike wat die Nederlandse tradisie in Afrikaans bestendig (Eksteen 1985:182). Selfs vandag is die invloed van Nederlands op Afrikaans nog te sien in die Afrikaanse ortografie, byvoorbeeld in die handhawing van $v$ en $f$, ei en $y$ (Eksteen 1985:185-186), hoewel die onderskeid nie in Afrikaans so prominent is soos in Nederlands nie, asook in die woordeskat, byvoorbeeld briewebesteller, felisitasie, felisiteer, gebroeders, gewente, pardon, en telefoneer om maar enkeles te noem (Taalkommissie 2009). Nederlands het dus 'n blywende invloed op die ortografie van Afrikaans uitgeoefen. 


\section{SLOT}

In hierdie artikel is aangetoon dat, alhoewel die US se Departement Afrikaans en Nederlands deur die werk van Mansvelt 'n belangrike begin gemaak het tot die Afrikaanse leksikografie, almal nie uit die staanspoor oortuig was dat Afrikaans sigself op leksikografiese gebied moes laat geld nie. Te midde van ' $n$ fel Nederlands-Afrikaans-stryd tussen dosente van die Departement Afrikaans en Nederlands aan die een kant en sy studente aan die ander kant, het die Departement Afrikaans en Nederlands deur die betrokkenheid van sy dosente by die woordeboek vir spesiale doeleindes, die Afrikaanse woordelys en spelreëls, oor die verloop van jare 'n belangrike bydrae gelewer tot die ontwikkeling van die Afrikaanse ortografie. Die Nederlands-Afrikaans-stryd het egter telkens kop uitgesteek en daar is dikwels op Nederlands gesteun. Ten spyte van 'n geleidelike wegbeweging van Nederlands in die rigting van die verafrikaansing van die spelreëls, het Nederlands ' $n$ blywende invloed op die Afrikaanse ortografie uitgeoefen. Die vasgryp aan Nederlands in die leksikografiese vergestalting van Afrikaans sou later ook oorspoel na ander leksikografiese bronne wat in 'n opvolgartikel ondersoek sal word.

\section{BIBLIOGRAFIE}

Boshoff, S.P.E. 1920. Taalstrijd. Die Banier, Oktober:107-109.

Boshoff, S.P.E. 1926. 'n Standaardwoordeboek van Afrikaans. In Gedenkboek ter eere van die Genootskap van Regte Afrikaners (1875-1925). Potchefstroom: Afrikaanse Studentebond, pp. 307-328.

Boshoff, S.P.E. et al. 1931 (vierde, hersiene en vermeerderde druk). Afrikaanse woordelys en spelreëls. Bloemfontein: Nasionale Pers.

Boshoff, S.P.E. et al. 1937 (vyfde, hersiene en vermeerderde druk). Afrikaanse woordelys en spelreëls. Bloemfontein: Nasionale Pers.

Boshoff, S.P.E. et al. 1953 (sesde, hersiene druk). Afrikaanse woordelys en spelreëls. Kaapstad: Nasionale Boekhandel.

Bosman, F.C.L. 1931. Die nuwe Afrikaanse woordelys en 'n nuwe Engels-Afrikaanse woordeboek. De Kerkbode, 3 Junie:29-30.

Bosman, D.B. et al. 1921 (derde, hersiene druk). Afrikaanse woordelys en spelreëls. Bloemfontein: Die Nasionale Pers.

Bosman, F.C.L. 1959. Geskiedkundige oorsig van die Suid-Afrikaanse Akademie vir Wetenskap en Kuns. In T.E.W. Schumann et al. (reds.). Feesalbum 1909-1959. Pretoria: J.L. van Schaik, pp. 73-166.

Claassen, L.H. 1977. Die ontstaansgeskiedenis van die Suid-Afrikaanse Akademie vir Taal, Lettere en Kuns. Ongepubliseerde MA-verhandeling. Johannesburg: Randse Afrikaanse Universiteit.

Combrink, J.G.H. 1991a. Nederlandse spelling geen reddingsgordel vir Afrikaans nie. Die Burger, 17 Julie:13.

Combrink, J.G.H. 1991b. Gids by die Afrikaanse woordelys en spelreëls. Kaapstad: Tafelberg.

Combrink, J.G.H. 1991c. Standaardafrikaans: Een van die versameling geslypte edelstene. Die Volksblad, 9 Mei:7.

Du Toit, P.S. 1966. Die Fakulteit van Lettere en Wysbegeerte. In H.B. Thom et al. (reds.). Stellenbosch 1866-1966. Honderd Jaar Hoër Onderwys. Kaapstad: Nasionale Boekhandel, pp. 71-97.

Du Toit, P.S. \& G.S. Venter. 1966a. Van Gimnasium tot Kollege, 1866-1887. In H.B. Thom et al. (reds.). Stellenbosch 1866-1966. Honderd Jaar Hoër Onderwys. Kaapstad: Nasionale Boekhandel, pp. 14-37.

Du Toit, P.S. \& G.S. Venter. 1966b. Die Victoria-Kollege, 1887-1918. In H.B. Thom et al. (reds.). Stellenbosch 1866-1966. Honderd Jaar Hoër Onderwys. Kaapstad: Nasionale Boekhandel, pp. 38-61.

Eksteen, L.C. 1985. Die rol van die Akademie in die standaardisering van die Afrikaanse spelling. Stellenbosch Papers in Linguistics Plus, 10:169-200.

Elffers, H. \& W.J. Viljoen. 1908. Beknopt Nederlands Woordeboek voor Zuid-Afrika. Kaapstad: J.C. Juta \& Co.

Gericke, W. 1991a. Vroeë woordelyste en woordeboeke in verband met Afrikaans. Lexikos, 1:104-112.

Gericke, W. 1991b. Die Woordeboek van die Afrikaanse Taal - 'n kultuurhistoriese verkenning. Ongepubliseerde MA-verhandeling. Stellenbosch: Universiteit van Stellenbosch. 
Gouws, R. 1995. Ou wyn in nuwe sakke: 'n Metaleksikografiese herwaardering van enkele komponente in Mansvelt se Idioticon. In N. Bosman (red.). 'n Man van Woorde. Pretoria: J.L. van Schaik, pp. 42-58.

Gouws, R.H. 2003. Oor patriotte en ander leksikografiese vernuwers. In W. Botha (red.). 'n Man wat beur. Stellenbosch: Buro van die WAT, pp. 71-85.

Gouws, R.H. \& F.A. Ponelis. 1992. Issues in the development of Afrikaans lexicography. South African Journal of Linguistics, Supplement 12:1-44.

Gouws, R.H. \& D.J. Prinsloo. 2005. Principles and Practice of South African Lexicography. Stellenbosch: SUN PReSS.

Grant, A.P. 2015. Lexical borrowing. In J.R. Taylor (ed.). The Oxford Handbook of the Word. Oxford: Oxford University Press, pp. 431-444.

Grosskopf, J.F.W. 1917. Boekbespreking. Afrikaanse woordelijs en spelreëls. Het Volksblad, 19 Oktober:7. Hiemstra, L.W. 1918. Brief aan die redaksie van Die Huisgenoot, 1 Junie. [Oorspronklike kopie in die J.J. Smith-versameling (versameling 333) van die J.S. Gericke Biblioteek, Universiteit Stellenbosch.]

Kapp, P. 2009. Draer van 'n droom. Hermanus: Hemel \& See Boeke.

Kapp, P. 2013. Maties en Afrikaans: 'n Besondere verhouding, 1911-2011. Pretoria: Protea Boekhuis.

Kotzé, D.J. 1966. Stellenbosch se Bydrae. In H.B. Thom et al. (reds.). Stellenbosch 1866-1966. Honderd Jaar Hoër Onderwys. Kaapstad: Nasionale Boekhandel, pp. 437-529.

Kroes, G. 1985. Die doeltreffendheid van die Afrikaanse woordelys en spelreëls as handleiding en naslaanbron by die onderrig van Afrikaans op tersiêre vlak. Stellenbosch Papers in Linguistics Plus, 10:328-344.

Le Roux, T.H. 1926. Die geskiedenis van die Afrikaanse spelling. In Gedenkboek ter eere van die Genootskap van Regte Afrikaners (1875-1925). Potchefstroom: Afrikaanse Studentebond, pp. 256-277.

Le Roux, T.H., D.F. Malherbe \& J.J. Smith. 1917. Afrikaanse woordelijs en spelreëls. Bloemfontein: Het Volksblad-drukkerij.

Le Roux, T.H., D.F. Malherbe \& J.J. Smith. 1918 (tweede druk). Afrikaanse woordelijs en spelreëls. Bloemfontein: Die Volksblad-drukkerij.

Logeman, W.S. 1897. Leesboek en Grammatika met Oefeningen en Woordenlijst Hollandsch-Engelsch. Kaapstad: Jacques Dusseau \& Co.

Malan, S.I. 1963. Die spelling van Afrikaans. Ongepubliseerde D.Litt.-proefskrif. Bloemfontein: Universiteit van die Oranje-Vrystaat.

Malan, S.I. 1974. Die groei van Afrikaans as skryftaal. In B. Kok (red.). Afrikaans: Ons pêrel van groot waarde. Johannesburg: Federasie van Afrikaanse Kultuurvereniginge, pp. 279-293.

Malherbe, D.F. 1926. Verslag van 'n vergadering van die Spellingkommissie van die Suid-Afrikaanse Akademie gehou in Pretoria op 28 en 29 September 1926. Tydskrif vir Wetenskap en Kuns, 5(2), Desember:105-109.

Malherbe, D.F. 1931. Die Akademie-spelling. Die Burger, 4 Mei:4

Mansvelt, N. 1884. Proeve van een Kaapsch-Hollansch Idioticon met Toelichtingen en Opmerkingen betreffende Land, Volk en Taal. Kaapstad: Cyrus J. Martin.

McLachlan, T. 2012. Bondige oorsig van die standaardiseringsgeskiedenis van Afrikaans. In K.K. Prah (red.). Veelkantiger Afrikaans. Streeksvariëteite in die Standaardvorming. Kaapstad: CASAS, pp. 16-29.

Morkel, A. 2009. Boekbespreking: Afrikaanse woordelys en spelreëls. Die Afrikaner, 2 Julie:6.

Nienaber, G.S. 1959. Die Tweede Afrikaanse Beweging. In T.E.W. Schumann et al. (reds.). Feesalbum 1909-1959. Pretoria: J.L. van Schaik, pp. 34-39.

Nienaber, P.J. 1968. Wat doen die Akademie? Kaapstad: Nasionale Boekhandel.

Nienaber, P.J. \& J.A. Heyl (reds.). s.a. Pleidooie in belang van Afrikaans. Deel II. Kaapstad: Nasionale Boekhandel.

Odendal, F.F. 1984. Die Afrikaanse taal 75 jaar. Tydskrif vir Geesteswetenskappe, 24(4), Desember:190-206.

Preller, G.S. 1926. Laatstaan die spelling! Ons Vaderland, 31 Desember:4.

Schoonheim, F. 1998. Een studie naar aspecten van de invloed van de Nederlandse lexicografie op Afrikaanse woordenboeken. Ongepubliseerde MA-verhandeling. Stellenbosch: Universiteit van Stellenbosch.

Smith, J.J. 1920a. Wysiginge in die Afrikaanse spelling goedgekeur deur die Suid-Afrikaanse Akademie vir Taal, Lettere, en Kuns, in Januarie 1920. Die Huisgenoot, Maart:329.

Smith, J.J. 1920b. Die spellingprotes van die Noorde. Die Huisgenoot, November:295.

Snijman, F.J. (hoofred.). 1964. U woorde, u woordeboek. Stellenbosch: Raad van Beheer oor Die Afrikaanse Woordeboek. 
Steyn, J.C. 1987. Trouwe Afrikaners. Kaapstad: Tafelberg.

Stolberg, D. 2015. Changes Between the Lines: Diachronic contact phenomena in written Pennsylvania German. Berlin: Walter de Gruyter.

Swart, C. 2009. Nuwe AWS op rak. Volksblad, 20 Julie:6.

Taalkommissie (van die Suid-Afrikaanse Akademie vir Wetenskap en Kuns). 1964 (sewende, verbeterde uitgawe). Afrikaanse woordelys en spelreëls. Kaapstad: Tafelberg.

Taalkommissie (van die Suid-Afrikaanse Akademie vir Wetenskap en Kuns). 1991 (agste, hersiene uitgawe). Afrikaanse woordelys en spelreëls. Kaapstad: Tafelberg.

Taalkommissie (van die Suid-Afrikaanse Akademie vir Wetenskap en Kuns). 2002 (negende, verbeterde en omvattend herbewerkte uitgawe). Afrikaanse woordelys en spelreëls. Kaapstad: Pharos.

Taalkommissie (van die Suid-Afrikaanse Akademie vir Wetenskap en Kuns). 2009 (tiende, verbeterde en omvattend herbewerkte uitgawe). Afrikaanse woordelys en spelreëls. Kaapstad: Pharos.

Van der Merwe, H.J.J.M. 1968. Patriot-woordeboek (heruitgawe). Pretoria: J.L. van Schaik.

Van der Merwe, H.J.J.M. 1971. Vroeë Afrikaanse Woordelyste. Pretoria: J.L. van Schaik.

Van Keymeulen, J. 2010. Standaardisatie en destandaardisatie bij Vlamingen en Afrikaners. Parallellen en verschillen. In M. van der Wal \& E. Francken (reds.). Standaardtalen in Beweging. Amsterdam: Stichting Neerlandistiek VU, pp. 135-152.

\section{Bronne sonder 'n identifiseerbare outeur}

Afrikaanse woordelys. 1953. Die Brandwag, 4 September:6, 55.

Die spellingooreenkoms. 1932. Die Huisgenoot, 23 September:35.

Geen nuwe spelling beoog nie. 1930. Die Burger, 8 Augustus:11.

Hersien spelling van Afrikaans. 1928. Die Volksblad, 11 April:7.

Minister gryp in in spellingkwessie. 1933. Die Burger, 3 Junie:1.

Nuwe spellingvoorstelle. 1926. Ons Vaderland, 31 Desember:4.

Prof. J.J. Smith oor fonetiese spelling. 1930. Die Volkstem, 12 Augustus:1.

Protes teen spelling-wysiging. 1920. De Burger, 8 September:3.

Spellingveranderings in Afr. 1928. Die Volksblad, 26 September:7.

Spelling-vergelyk word bekend gemaak. 1930. Die Burger, 27 September:7, 9.

Uit ons eie boekrak. 1954. Die Taalgenoot, Januarie:29, 31. 